\title{
How to Write a Corporate Image Brochure People Will Truly Want to Read
}

\author{
COMMUNICATION CORNER No. 29
}

\author{
by Philip Yaffe
}

\begin{abstract}
Editor's Introduction
Each "Communication Corner" essay is self-contained; however, they build on each other. For best results, before reading this essay and doing the exercise, go to the first essay "How an Ugly Duckling Became a Swan," then read each succeeding essay.

Most companies and organizations of any size produce and distribute glossy brochures to enhance their image. Most such publications are largely a waste because they are seldom read, even by employees and members of these companies and organizations. But it doesn't have to be that way. Here is an approach to help ensure that such image brochures are actually worth the time and money expended on them.
\end{abstract}




\title{
How to Write a Corporate Image Brochure People Will Truly Want to Read
}

\author{
COMMUNICATION CORNER No. 29
}

\section{by Philip Yaffe}

Writing a corporate (or association, or organization) image brochure is truly a study in futility. Two things are certain about these expensive, glossy booklets:

1. Almost all companies of any size feel compelled to produce them.

2. Virtually no one ever reads them.

It is not difficult to understand why. It's in the name. Most such brochures are far too concerned with "image," i.e. making the company look good, than with communicating with readers. So why should people read it?

The solution to the problem is well known: Write from the reader's point of view. But while everyone may know this, hardly anyone actual does it. They think they do, but they don't. Too often the rationale for the brochure is, "This is interesting and important information, so people will surely want to read it." This is not writing from the reader's point of view, but the company's point of view.

The results of this self-delusory approach to image brochures are plain to see: high costs and low value.

But it doesn't have to be this way. Some years ago, I was commissioned to write a corporate image brochure for a pharmaceutical company. When it was printed, not only did people read it, they actually called the company to request additional copies to give to friends, clients, and professional colleagues.

How did I achieve this miracle? You guessed it, by writing the brochure from the reader's point of view. But how did I know that I wasn't deluding myself, only thinking I was writing from the reader's point of view and not my client's?

I had help and guidance from what is known as the "expository writing attitude."

All writing can be divided into two broad categories: creative (fiction) and expository (nonfiction). Creative writing comprises texts such as short stories, novels, poems, radio plays, stage plays, television scripts, film scripts, etc. Expository writing comprises texts such as memos, reports, proposals, training manuals, brochures, newsletters, marketing proposals, research 
reports, etc. The approach the writer takes to these essentially different genres must also be essentially different.

Broadly speaking, the purpose of creative writing is to amuse and entertain, so when sitting down at the keyboard the fiction writer can assume "everyone will want to read what I am going to write." This is the "creative writing attitude."

The purpose of expository writing is usually to inform and instruct. When called upon to be informed and instructed, most people would very much prefer to be doing something else. So when sitting down at the, the expository writer is constrained to assume "no one will want to read what I am going to write." This is the "expository writing attitude."

This dreary description of the expository writer's challenge may seem a rather negative note on which to set about one's work. But is it really? If it is a realistic assessment of the situation, then it is the best starting point for defining and achieving a text's objectives. That can hardly be considered negative.

So how did I apply the expository writing attitude to produce a corporate image brochure that people not only read, but also recommended to their friends and colleagues?

Starting from the assumption that no one would want to read anything about the company, I and my colleagues (it was a brainstorming) asked ourselves: "What things does this company do that people might want to read about?"

Its basic activity was producing vaccines. We are all naturally interested in health, and virtually everyone knows the importance of vaccination, for themselves but especially for their children. Here were already two things people might want to read about.

We were given the assignment in the mid-1980s, just when a strange new term-genetic engineering-was beginning to appear more and more in newspaper headlines. According to the reports, this new technique would revolutionize medicine, so people were becoming more and more interested in learning what it was all about. This was a third topic of broad general interest.

To make a long story short, we defined seven areas of the company's activities that would be naturally attractive to potential readers. However; it didn't stop there. If all this exciting information were jumbled together with company propaganda, people probably still wouldn't want to read the brochure, despite their natural inclination to do so.

We therefore made a daring proposal. The brochure would be laid out in seven double-page spreads, i.e. each of the seven areas of activity would be allotted two facing pages. But the text would be rigorously segregated. 
1. Theory. The left side of each double-page spread would be pure science; the company's name would never even be mentioned.

2. Practice. The right page would explain how the company used the science explained on the left to produce vaccines.

When we presented the concept, the reaction was one of shock. "You mean people could read the brochure left side only and never even see our name?" Exactly. But having learned about the basic science, wouldn't they naturally want to learn how the company was using the science to produce safe, effective, and (relatively) inexpensive vaccines?

It took a while for management to accept the proposal, but finally they did. When the brochure was ready, they couldn't print enough of them.

Of course, not all companies would be suitable for this particular type of corporate image brochure. The important idea here is not this specific brochure, but the thinking process that led to it.

I subsequently wrote several other corporate brochures. None of them had quite the same overwhelming impact. However, all of them received positive feedback. Not only from the company's management, but also from the people who really count the readers for whom they were intended.

The next time you sit down to compose an image brochure (or virtually any kind of expository text), ask yourself the question: I know that no one wants to read what I am going to write, so how can I write something they will want to read? Until you can find at least one good answer (preferably more), keep your hands away from the keyboard. You are simply not yet ready to start writing.

\section{About the Author}

Philip Yaffe was born in Boston, Massachusetts, in 1942 and grew up in Los Angeles, where he graduated from the University of California with a degree in mathematics and physics. In his senior year, he was also editor-in-chief of the Daily Bruin, UCLA's daily student newspaper. He has more than 40 years of experience in journalism and international marketing communication. At various points in his career, he has been a teacher of journalism, a reporter/feature writer with The Wall Street Journal, an account executive with a major international press relations agency, European marketing communication director with two major international companies, and a founding partner of a specialized marketing communication agency in Brussels, Belgium, where he has lived since 1974. He is the author of more than 30 books, which can be found easily in Amazon Kindle.

DOI: $10.1145 / 3419839$ 